\title{
Capillary (CE) and Cellulose Acetate (CAE) Electrophoresis of Polyethylene Glycol (PEG) Precipitated Serum proteins in Patients with subclinical hypothyroidism (SCHT)
}

\author{
Castagnino Juan', Scaglia Hugo ${ }^{2 *}$, Lopez Mercedes $^{2}$, Colombani ME ${ }^{2}$, Riesco Oscar ${ }^{3}$ and Ruffini \\ Maiangeles $^{3}$
}

${ }^{1}$ Laboratorio de Alta Complejidad Dr. Castagnino, Avellaneda, Argentina

${ }^{2}$ Instituto de Análisis Bioquímicos de Endocrinología, La Plata, Argentina

${ }^{3}$ Laboratorio Riesco General Pico La Pampa, Argentina

\section{SHORT COMMUNICATION}

In patients with SCHT, TSH levels are increased with normal thyroid hormone values with or without the presence of antithyroid antibodies. In these cases, demonstration of a TSH without biological activity would avoid treatment. This characteristic of TSH could be due, among other causes, to the binding to an autoantibody (BIGBIG TSH). PEG has been used to precipitate Gamma $(\gamma)$ Globulin. The objective of this study is to evaluate, in patients with SCHT, the

proteins of the supernatant from PEG precipitation by CE and CAE, in order to corroborate the specific precipitation of the protein.

PEG treatment was performed in the serum of 2 groups of SCHT, according to TSH levels ( $\mu \mathrm{UI} / \mathrm{ml}$ ); 1 : between 5 to 10 (n: 11); 2: more than 10 (n: 9) and a control group with TSH less than 5 (n: 10). Proteins were fractionated by CE and CAE in the supernatant of all sera.
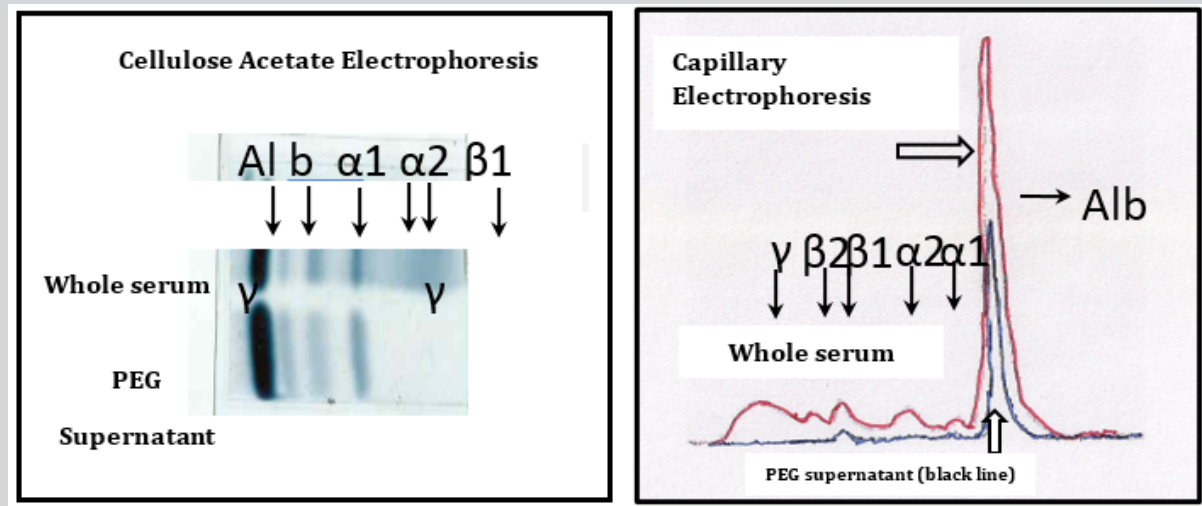

Figure 1

Quick Response Code:

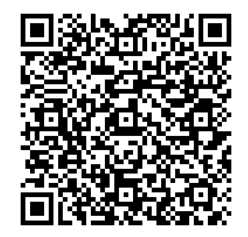

Address for correspondence: Scaglia Hugo, Instituto de Análisis Bioquímicos de Endocrinología, La Plata, Argentina

Received: March 28, $2020 \quad$ Published: April 07, 2020

How to cite this article: Castagnino J, Scaglia H, Lopez M, Colombani ME, Riesco O, Ruffini M. Capillary (CE) and Cellulose Acetate (CAE) Electrophoresis of Polyethylene Glycol (PEG) Precipitated Serum proteins in Patients with subclinical hypothyroidism (SCHT). 2020 - 2(2). OAJBS.ID.000162. DOI: $10.38125 /$ OAJBS.000162 
In all cases the results did not have significant differences between the groups as well as in the controls. The Figure 1 shows a representative example of the $\mathrm{CE}$ and CAE. Both methods showed that PEG totally precipitates $\gamma, \beta 2$ and $\beta 1$ and partially Albumin. Regarding $\alpha 1$ and $\alpha 2$ with CAE, a partial but total decrease was observed due to CE. Recently, a new patient with TSH levels of $71.11 \mu \mathrm{UI} / \mathrm{ml}$ and normal levels of free $\mathrm{T} 3$ and free $\mathrm{T} 4$, with a dilution profile that does not show parallelism with the standard curve and with an increase in the TSH fraction precipitated with PEG, chromatography in sephacryl S200 showed that only the serum has a monomer fraction. Assessing the possibility that the lack of activity was due to alterations of the glycoproteins, the chromatography in concanavalin A sepharose showed no increase in the less elaborate forms, hybrids without activity (Figure 2).

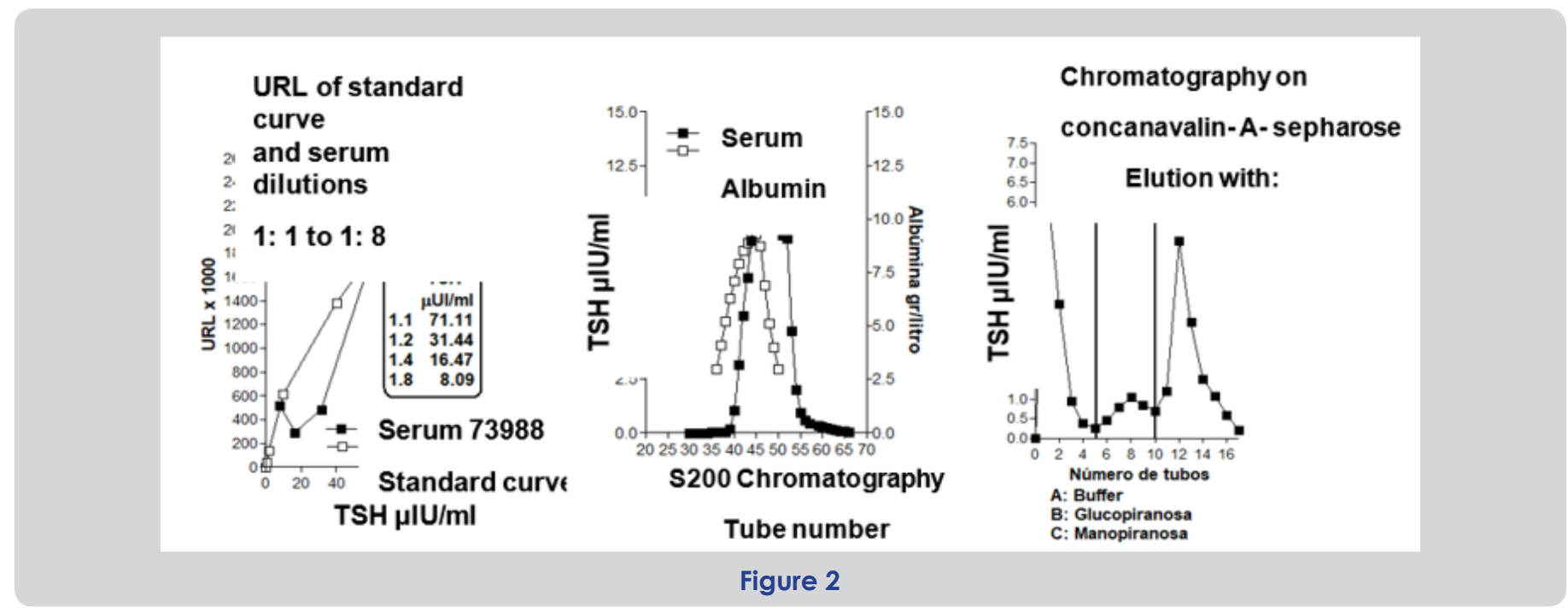

The results obtained demonstrate that PEG is not selective for $\gamma$. The most specific method for detecting BIG-BIG TSH is chromatography on Sephadex G 100. In our previous studies, the results with PEG in 20 patients with HTSC that showed an increase in the precipitate with PEG (macro TSH) whose result expressed as $\%$ of the precipitate was between 59.0-61.6 while in the controls it was 21.9-30.7 [1]. Of these patients, only 1 was positive on chromatography [2], possibly due to the non-specificity of the PEG. In the future, the difference in the binding of TSH to proteins precipitated with PEG should be studied and compared with the macro TSH evaluated by chromatography.

\section{REFERENCES}

1. Colombani-Vidal ME, Fernandez P, Guizburg M, Antista MS, Zylbersztein CC et al. (2012) IX congreso FASEN octubre de.

2. Lopez M, Colombani M E, Scaglia HE (2017) XX Congreso SAEM, octubre. In memory of Dr. Juan miguel castagnino. 